Jpn. J. Med. Mycol.

Vol. 34, 207-212, 1993

ISSN $0916-4804$

原著

\title{
Terbinafine のケラチン親和性に関する検討
}

\author{
内田勝 久 山口英世
}

帝京大学医真菌研究センター

〔受付 10 月 6 日, 1992 年. 受理 12 月 14 日, 1992 年 ]

\begin{abstract}
要 旨
新規アリルアミン采抗真菌剤 terbinafine の皮虙角質層における薬物動態に関する研究の一環として, 薬剤のケラチン吸着性およびケラチンに吸着された薬剤の遊離性について in vitro 実験系を用いて検 討した. 活性型薬剤の定量は, Trichophyton mentagrophytes を試験菌とする寒天ウエル法を用い

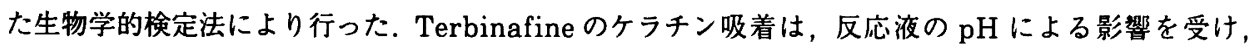
$\mathrm{pH} 7.0$ より $\mathrm{pH} 5.0$ で幾分高い吸着率を示した．しかし，吸着率はそれ以上に反応液中の薬剤とケラチ ンの重量比に強く依存し，中性域でこの比が $1: 100,1: 1,000$ および $1: 10,000$ の場合，それぞれ約 $48,73,88 \%$ の值を示した. 一旦ケラチンに吸着した薬郕もその後の洗浄操作によって容易に遊出され, 薬剂約 $80 \mu \mathrm{g}$ を吸着したケラチン $100 \mathrm{mg}$ を $5 \mathrm{ml}$ の pH 7.0 または 5.0 の緩衝液で 20 回洗浄すること によりほほ $100 \%$ の薬剤活性が洗浄液から回収された。 以上の結果から, terbinafine はケラチンに対 して比較的吸着されやすいがその結合はゆるやかであることが示され，したがって表在性真菌症の病巣 部位でもある表皮角質層は局所投与された terbinafine の良好なレザバーとして働き，活性型薬剤を効 率よく組織内に放出する可能性が示唆された.
\end{abstract}

Key words : terbinafine, ケラチン (keratine), Trichophyton mentagrophytes, 薬物動態 (pharmacokinetic)

\section{緒言}

抗真菌剤が表在性真菌症に対してすぐれた薬効 を発揮するための条件として, 薬剤が強い抗菌活 性を有することに加えて, 感染部位である表皮角 質層内で活性型薬剤が充分高いレベルで維持され ることが必要である.この角質層における薬物動 態には，その主要構成成分であるケラチンに対す る薬剤の親和性がとくに重要な役割を演じている と考えられる.

新規アリルアミン系抗真菌剤 terbinafine は， 皮废系状菌をはじめとして広範囲の病原真菌に対 して抗菌活性を有し1-4)，モルモットの体部白痽モ

別刷請求先 : 山口 英世 下192-03 東京都八王子市大塚 359 番地 帝京大学医真菌研究センター
デルにおいて 1 日 1 回の局所塗布ですぐれた治療 効果を示す5,6).ささらに白痽, 皮虚カンジダ症およ び癜風の患者に対する治療試験においても同様の 用法による有効性が証明されている6). Terbinafine の in vitro 抗 Candida 活性は比較的弱いとされ ている1-4). それにもかかわらず本剤の外用剤によ る局所療法が皮䖉カンジダ症に対して既存のイミ ダゾール系薬剤と遜色ない良好な治療効果を示す ことは，本剤の表皮角質層内における薬物動態が 好適である可能性を強く示唆する.

本報においては, terbinafineの表皮角質層内で の薬物動態を解析する研究の一環として, 本剂と ケラチンとの親和性を in vitro 実験系を用いて検 討した成績を述べる. 


\section{材料および方法}

\section{1. 薬㨈その他の試薬}

試験薬 terbinafine はサンド薬品(株より供与さ れた原末標品を用い, ジメチルスルホキシド （DMSO）に溶解して $1 \mathrm{mg} / \mathrm{ml}(\mathrm{w} / \mathrm{v})$ の溶液を 作製し原液とした。薬液の希釈はすべて DMSO を用いて行った。ケラチン粉末（ヒト毛髪由来， 東京化成, 特級) はエ夕ノール・エーテル（50： $50, \mathrm{v} / \mathrm{v})$ およびアセトンで数回洗浄し, デシケー ター中で乾燥した後, 実験に供した。

\section{2. 薬剤の生物学的検定法}

(i) 検定菌: Trichophyton mentagrophytes TIMM 1189 1/10 Sabouraud グルコース寒天 培地斜面に $27^{\circ} \mathrm{C}, 2$ 週間培養した後, 斜面部を $0.05 \%$ Tween 80 添加生理食塩水で覆い, 振晹に より分生子を遊離させた。これを滅菌ガーゼで滤 過して菌系塊を除去した。得られた分生子浮遊液 中の分生子数を血球計算板で算定した後, $2 \times 10^{7}$ 個 $/ \mathrm{ml}$ の濃度の浮遊液を調製した.

(ii) 検定用培地 : Bacto-peptone 1\%, グルコー ス $1 \%$, Dotite agarose-1 1\%からなる寒天培地 （pH 無修正）を用いた。

(iii) 薬剤標準液: Terbinafine 原液をもとに薬 剤の 2 倍希釈系列を作製し，その 1 容を $0.2 \mathrm{M}$ Tris-HCl 緩衝液（pH7.0）または $0.2 \mathrm{M}$ 酢酸一酢 酸ナトリウム紘衝液（pH5.0）99容に加えて10〜 $0.01 \mu \mathrm{g} / \mathrm{ml}$ の濃度範囲の薬液を調製した.

(iv) 検定実施法 : 検定菌分生子浮遊液 $0.7 \mathrm{ml}$ を 取り, $50^{\circ} \mathrm{C}$ に溶融保温した検定用培地 $70 \mathrm{ml}$ と混 釈し，4 個のステンレス製カップ（外径 $8 \mathrm{~mm}$, 高 さ $10 \mathrm{~mm}$ )を等間隔に並置した角型シャーレ（栄 研化学 1 号角シャーレ : $230 \times 79 \times 14.5 \mathrm{~mm}$ ）に注 いだ. 寒天が固まった後, カップを取り除き，で きたウエルに薬剤標準液または検体を $0.2 \mathrm{ml}$ 注入 した. 各シャーレを $27^{\circ} \mathrm{C}, 48$ 時間インキュベート した後, 生じた阻止円の直交する二方向の直径を 計測して平均値を求めた. 各濃度の薬剤標準液に ついて得られた值に基づいて標準曲線を作成した 後, 検体での值を挿入して薬剤濃度を算出した.

\section{3. ケラチンへの薬剤吸着性の測定}

ケラチン 10,100 および $1,000 \mathrm{mg}$ を予め入れて おいた L 型試験管（内径 $18 \mathrm{~mm}$ ) に, 緩衝液 9.9 $\mathrm{m} l$ および薬剤原液 $(1 \mathrm{mg} / \mathrm{m} l) 0.1 \mathrm{ml}$ を加え, 37
${ }^{\circ} \mathrm{C}, 30$ 分間振盪培養 (100 回/分) した. インキュ ベーション終了後, 遠心 (300rpm, 5 分間)を行っ て未吸着の薬剤を含む上清と沈渣（ケラチン）と を分別した。 上清画分の一部を検体として用い， 上記検定法により含有薬剤濃度を測定した。得ら れた未吸着薬剤量の值に基づいてケラチンへの薬 剤吸着率を算出した。一方, 沈渣は次に述べる薬 剂遊出試験に用いた。

\section{4. ケラチンからの薬剤遊出率の測定}

薬剤を吸着したケラチンからなる沈渣画分に緩 衝液 $5 \mathrm{ml}$ を加えて充分に擋找混和し, $37^{\circ} \mathrm{C}, 10$ 分 間インキュベートした後, 再び遠心を行って上清 と沈渣の両画分に分けた。この洗浄操作を 20 回 くり返し行い, 各回の上清画分の薬剤濃度を上記 検定法により測定してケラチンから遊出される薬 剤量を求め, その総量から遊出率（回収率）を算 定した。

\section{結果}

\section{Terbinafine の生物学的検定法}

種々の皮府系状菌菌株揖よび Candida 属菌種菌 株を検定菌として用い, 寒天ウエル法での terbinafine 検定の予備実験を行った（未発表）。その 結果, T. mentagrophytes を用いた場合に，感度， 測定可能域の広さ，再現性のいずれの点でも最も 良好な検量曲線が得られることが判明した．Fig. 1 に典型的な検量曲線を示した。薬剤濃度 0.078 $5 \mu \mathrm{g} / \mathrm{ml}$ の範囲で良好な直線関係が得られた。こ の検量曲線を実験ごとに作成し，同時に得られる 検体の測定値をこれに内挿して検体中の薬剤濃度 を算出した。

\section{Terbinafine のケラチンへの吸着}

本実験条件下における terbinafine のケラチン 吸着率は, Table 1 に示したように, 薬剤/ケラチ

Table 1. Absorption of terbinafine to keratine when mixed together in buffer at pH7.0 and 5.0 and incubated at $37^{\circ} \mathrm{C}$

\begin{tabular}{ccc}
\hline \multirow{2}{*}{$\begin{array}{l}\text { Terbinafine/keratine } \\
\text { ratio }(\mathrm{w} / \mathrm{w}) \text { in the } \\
\text { incubation mixture }\end{array}$} & \multicolumn{2}{c}{ Absorption rate (\%) at : } \\
\cline { 2 - 3 } & $\mathrm{pH} 7.0$ & $\mathrm{pH} 5.0$ \\
\hline $1: 100$ & 48.2 & 51.5 \\
$1: 1,000$ & 73.0 & 79.2 \\
$1: 10,000$ & 88.4 & 98.0 \\
\hline
\end{tabular}




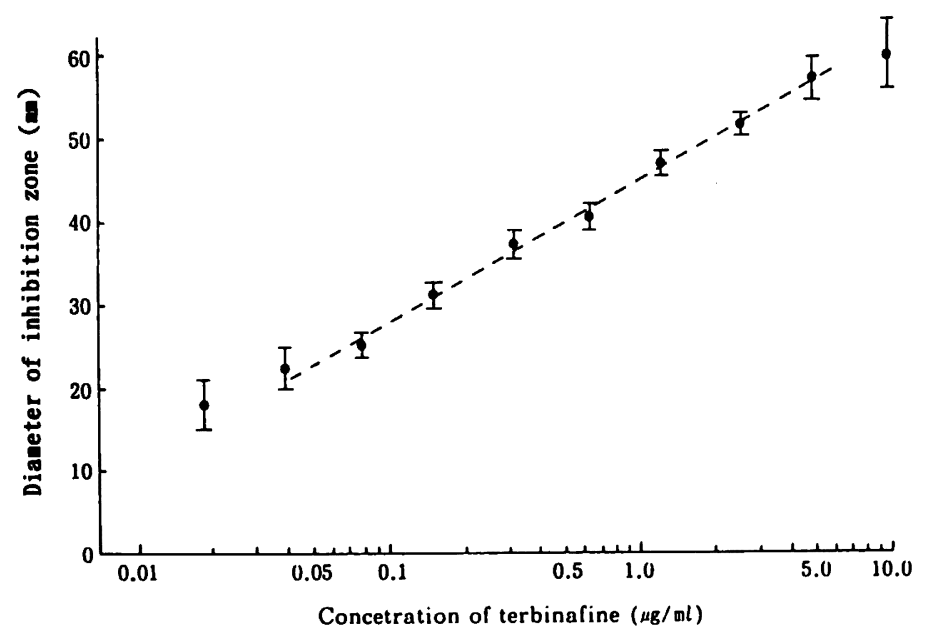

Fig. 1. Dose-response curves for terbinafine obtained by bioassay using well agar plate method with Trichophyton mentagrophytes TIMM 1189 as the assay organism.

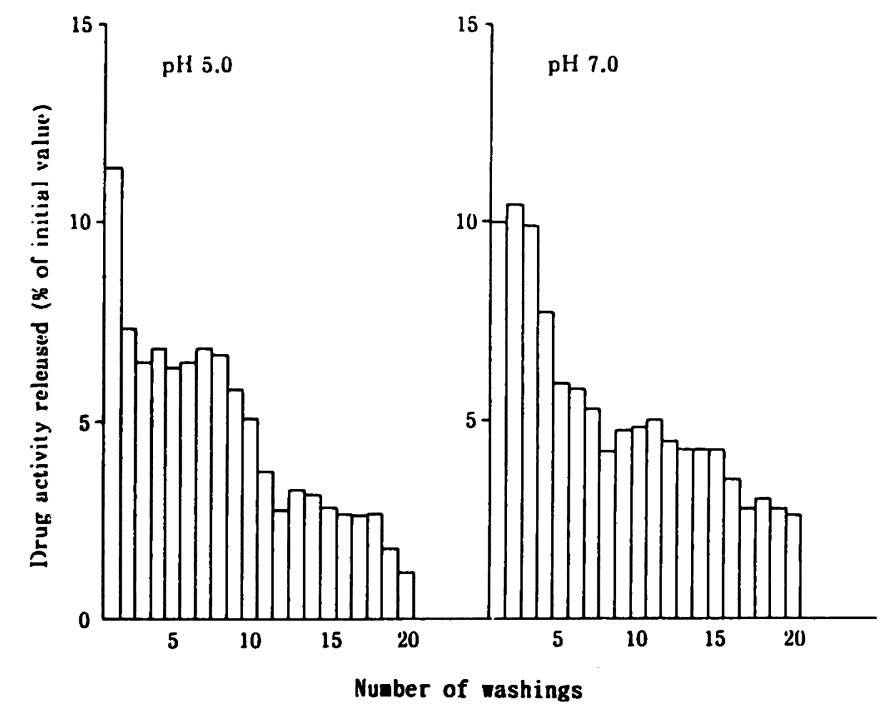

Fig. 2. Release of drug by washing with buffer from terbinafinepreloaded keratine.

ン重量比が減少するにつれて上昇した。また,こ の重量比が同一であっても反応液の $\mathrm{pH}$ が中性域 (pH7.0)にあるよりも酸性域（pH5.0）にあるほ うがより高い吸着率を示した。薬剤/ケラチン比 が $1: 100,1: 1,000$ および $1: 10,000$ の場合, $\mathrm{pH}$ 5.0 での吸着率はそれぞれ約 52,79 および $98 \%$, pH 7.0 ではそれぞれ約 $48,73,88 \%$ の値を示した.

\section{3. ケラチンに吸着した薬剤の溶出}

$\mathrm{pH} 7.0$ および $\mathrm{pH} 5.0$ の緩衝液 $10 \mathrm{ml}$ 中で薬剤 $100 \mu \mathrm{g}$ とケラチン $100 \mathrm{mg}$ を反応させ薬剤をそれ ぞれ $73 \mu \mathrm{g}, 79.2 \mu \mathrm{g}$ 吸着したケラチン $100 \mathrm{mg}$ を， 対応する緩衝液毎回 $5 \mathrm{ml}$ を用いて 20 回洗浄を行 い, 各回の洗浄液中に遊出される薬剂量を検定し た. Fig. 2 に示したような経過で, 洗浄液の $\mathrm{pH}$ とはほとんど関係なく, 薬剤は容易にケラチンか 
ら遊出され，20 回洗浄後の回収率はほほ $100 \% に$ 達した。

以上の Terbinafine のケラチンへの吸着および 溶出に関する実験成績は, 再度の実験により再現 性が確認された。

\section{考察}

表在性皮膚真菌症における感染病巣すなわち起 因菌の生息部位は，表皮角質層に限られるので， 抗真菌化学療法を行った場合の治療効果は, 薬剤 の in vitro抗菌活性に加えて, 皮虚組織とくに表 皮角質層内での薬物動態に支配される．外用抗真 菌剂の薬物動態に関しての望ましい性質は，皮痛 表面から浸透した薬剤が活性型のまま角質層内に 充分な時間つまり起因菌と接触して抗菌作用を発 揮しうるに足りる時間留まることである。ヒトゃ 実験動物の皮虚へ塗布された抗真菌剂の経皮吸収 の研究は，従来から多くのイミダゾール系薬剤7)

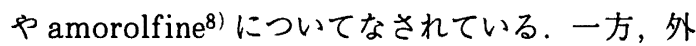
用抗真菌剂の皮虐組織内分布に関する報告は比較 的少ないが, ${ }^{14} \mathrm{C}$-標識薬剤を用いた局所皮虑組織 のオートラジオグラフィーまたは連続剥離切片 試料の放射能測定などの方法によって bifonazole $^{9,10)}$, clotrimazole ${ }^{10)}$ などのイミダゾール系薬 剤, さらに最近ベンジルアミン系薬剤 KP-36311) などで検討されている.

しかしながらこの方法では局所組織内に存在 する薬剤の総量や濃度は推定できるとしても，そ のなかで活性型薬剤がどの程度の比率を占めるか についての手掛りとなる情報はまったく得られな い.これとは別に，皮膚組織内で有効に働く薬 剤の貯留時間を間接的に推定する方法として， Plempel ら 12)はモルモット背部の感染予定部位に 予め試験薬剤を 1 回塗布しておき, 24 96 時間後 に白癖菌を感染させた後の発症の有無や生じる病 変の程度を観察するという感染予防試験を考案し， bifonazole などの薬剤について実験を行っている. また, Polak ${ }^{13)}$ および著者ら ${ }^{14)}$ はこれと基本的に 同一の実験系を用い, amorolfine や bifonazole 同様の良好な皮虐貯留性を示すことを報告した。 しかし，この試験法は方法論的な制約から皮虚組 織内に存在する薬剤の濃度を数量的に表わすこと ができないという大きな欠点をもっている.

皮膚組織とくに表皮角質層内に浸透し貯留した
薬剤がどの程度の治療効果を発揮するかは，角質 層内で得られる薬剤濃度および薬剤のケラチンと の親和性によってもっぱら規定されると考えられ る. Terbinafineについては, 薬剤の皮虐組織内分 布のデータがすでに得られているところから15)， 今回は薬剤のケラチン親和性を検討することを試 みた。実際に使用した実験系は, 試験管内で一定 濃度の薬剤とケラチンを緩衝液中でインキュベー トし,ケラチンへの薬剤の吸着率および薬剤を吸 着したケラチンからの遊出率を，外液から回収さ れる薬剤の活性に基づいて測定するというもので ある．角質層を含めて皮虚組織内の $\mathrm{pH}$ はふつう 中性域にあるといわれているので，反応には $\mathrm{pH}$ 7.0 の緩衝液を用いた。これに加えて, terbinafine は塩酸塩として製郕化されているため, 浸透した 薬剤によって皮㲊組織内の $\mathrm{pH}$ が低下する可能性 を考慮し, pH5.0の緩衝液も併用した。

実験の結果によれば, terbinafine のケラチンへ の吸着は $\mathrm{pH}$ によっても幾分影響を受け，酸性側 $\mathrm{pH}$ でより吸着しやすくなる傾向がみられた，し かし，吸着率は主として反応液中の薬片/ケラチ ン比に依存しこの比が $1: 100$ から $1: 10,000$ に 増えた場合には吸着率は 48～52\% から 88～98\% に上昇した. ${ }^{14} \mathrm{C}$-標識 terbinafine $1 \%$ クリーム剤 をラット背部皮䖉に単回塗布して行った皮内分布 の成績15)によれば, 24 時間後には表皮角質層に 対応する深さの皮䖉組織から約 $1 \sim 2 \mathrm{mg} / \mathrm{g}$ の薬剤 濃度に相当する放射能が回収される。したがって， 薬㓮と皮虚組織の重量比は $1: 1,000$ のオーダーと みなされている。一方，今回のモデル実験系にお いて薬剤/ケラチン比を $1: 1,000$ とした場合の薬 片吸着率は 73〜 79\% であり，この値を上述の in vivo 実験系の成績に嵌めると, 表皮角質層内に存 在する薬剂濃度の約 $20 \sim 30 \%$ に相当する 200 $600 \mu \mathrm{g} / \mathrm{ml}$ と折るルが遊離型薬郕で占められると いう計算になる。この濃度は皮虑系状菌に対す る本剤の $\mathrm{MIC}$ 值 ${ }^{1-3)}$ よりも数万倍以上高く, $C$. albicans 臨床分離株に対する平均 MIC 值4)をも 上回っており, terbinafine $1 \%$ クリーム剤の 1 日 1 回塗布による皮虚カンジダ症に対する臨床的有 効性を充分説明するものである.

これに加えて，一旦ケラチンに吸着された薬剂 が pH5〜7の緩衝液で洗浄するだけで容易に遊出 され，ほほ $100 \%$ の活性が外液中に回収されるこ 
とが観察された。このことから，おそらく生体の 表皮角質層内ではケラチンが皮膚表面から浸透し てきた薬剤のレザバーとして働き, 組織内の遊離 型薬凨の濃度低下に伴って, 先に結合した薬剤が 放出される可能性を示唆するものと思われる. 実 際に, この過程が起こるとすれば，ヶラチンが活 性型薬侴濃度の維持に役立ち, 治療上有益な効果 をもたらすものと考えられる.

\section{文献}

1) Petranyi G, Meingassner JG, Mieth $H$ : Antifungal activity of the allylamine derivative terbinafine in vitro. Antimicrob Agents Chemother $31: 1365-1368,1987$.

2) Shadomy S, Espinel-Ingroff A, Gebhart $\mathrm{RJ}$ : In vitro studies with SF86-327, a new orally active allylamine derivative. $\mathrm{J}$ Med Vet Mycol $23: 125-132,1985$.

3）平谷民雄, 浅黄友季世, 山口英世 : アリルアミン 系抗真菌片 Terbinafine の in vitro 抗菌活性に 関する研究. 真菌誌 $32: 323-332,1991$.

4) 内田勝久, 山口英世 : アリルアミン系抗真菌剤 Terbinafine $の$ in vitro 抗菌活性に関する研究. 第 2 報 Candida albicans 新鮮臨床分離株の薬 剤感受性. 真菌誌 34, 1993 (印刷中).

5) Petranyi G, Meingassner JG, Mieth H: Activity of terbinafine in experimental fungal infections of laboratory animals. Antimicrob Agents Chemother $31: 1558$ $1561,1987$.

6）内田勝久，山口英世 : モルモットの実験的白癖に 対する新規アリルアミン系化合物 Terbinafine クリーム郕の 1 日 1 回用法による治療効果. 真菌 誌 $32: 333-342,1991$.

7) Ritter W : Pharmacokinetics of azole compounds. In: (Bey D and Plempel $\mathrm{M}$ ed.) Sterol Biosynthesis In hibitors. p.397-429,
Ellis Horwood, Cliduster (England), 1988.

8) Rhode E, Zaug M, Hartmann D : Preliminary clinical experience with Ro 14-4767 (amorolfine) in superficial mycoses. In: (Fromtling RA ed.) Recent Trends in the Discovery, Development and Evaluation of Antifungal Agents. p.575-582, J. R. Prous Science Publ, Barcelona, 1987.

9) Patzschke K, Ritter W, Siefert HM, Weber $\mathrm{H}$, Wegner LA: Pharmacokinetic studies following systemic and topical administration of $\left[{ }^{14} \mathrm{C}\right]$ bifonazole in man. ArzneimForsch/Drug Res 33 : 745-750, 1983.

10) Lücker $P W$, Beubler E, Kukovetz WR, Ritter W : Retention time and concentration in human skin of bifonazole and clotrimazole. Dermatologica 169 : suppl. 1, 51-56, 1984.

11）有可 正, 羽瀬豊治，横尾 守: 外用抗真菌剂の 感染局所における抗菌活性に関する一考察一皮唐 透過性と角質への吸着性について一。西日皮虐 52 : 545-548, 1990.

12) Plempel $M$, Regel $E$, Büchel $\mathrm{KH}$ : Antimycotic efficacy of bifonazole in vitro and in vivo. Arzneim-Forsch/Drug Res $33: 517-524,1983$.

13) Polak A : Antifungal activity of four antifungal drugs in the cutaneous retention time test. J Med Vet Mycol 22 : 501-593, 1984.

14）内田勝久，山口英世：モルモットにおける実験的 白癖菌感染に対するモルホリン系抗真菌剤 Amorolfine の発症予防効果及びそれを指標と する作用持続性の検討. Jap J Antibiotics 44: 1032-1041， 1991.

15）田野倉吉則 他： $\left[{ }^{14} \mathrm{C}\right] \mathrm{SF} 86-327$ ラット単回経 皮投与後における皮内分布試験（サンド薬品(侏) 資料） 


\title{
Studies on the Affinity of Terbinafine with Keratine
}

\author{
Katsuhisa Uchida, Hideyo Yamaguchi \\ Research Center for Medical Mycology, Teikyo University School \\ of Medicine, 359 Otsuka, Hachioji, Tokyo 192-03
}

To obtain information on the pharmacokinetic property of a new antifungal drug terbinafine (TBF) in the honey layer of the epidermis absorbability of the drug added to the ambient buffered medium ( $\mathrm{pH} 5$ or 7 ) to keratine and release of the keratine-preloaded drug to the medium was studied using human-derived keratine powder. Determination of the drug in an active from was made biologically using the conventional agar-well diffusion method with Trichophyton mentagrophytes as the testing organism.

The absorption rate of TBF to keratine was slightly influenced by $\mathrm{pH}$ of the medium; higher values were obtained at $\mathrm{pH} 5$ than $\mathrm{pH} 7$. The drug absorption rate was more highly dependent upon the ratio of the drug weight to keratine weight $(\mathrm{D} / \mathrm{K}$ ratio) in the reaction mixture, showing values of approx. 48,73 and $88 \%$ at $\mathrm{pH} 7$ in $\mathrm{D} / \mathrm{K}$ ratios of $1: 100,1: 1,000$ and 1 : 10,000 , respectively. However, the drug activity was almost completely removed from keratine and recovered in the washing medium after TBF-bound keratine was washed thoroughly with buffered solution ( $\mathrm{pH} 5$ or 7 ). These results proved that although TBF molecules can be absorbed to keratine at a relatively high rate, they are easily released without losing their activity. Therefore, we are led to the prossibility that the honey layer of the epidermis in the host acts as a reservoir for TBF administered topically to release the active drug efficiently into the tissue. 